NBER WORKING PAPER SERIES

\title{
LABOR MARKET NATIONALIZATION POLICIES AND EXPORTING FIRM OUTCOMES: \\ EVIDENCE FROM SAUDI ARABIA
}

\author{
Patricia Cortés \\ Semiray Kasoolu \\ Carolina Pan \\ Working Paper 29283 \\ http://www.nber.org/papers/w29283
NATIONAL BUREAU OF ECONOMIC RESEARCH
1050 Massachusetts Avenue
Cambridge, MA 02138
September 2021

Research support from the Saudi Ministry of Economic Planning (MEP) is gratefully acknowledged. We thank Ricardo Hausmann, David McKenzie, Jennifer Peck, MEP staff, and seminar participants at the 13th Migration and Development Conference and the Economics of Migration seminar for helpful comments. The views expressed herein are those of the authors and do not necessarily reflect the views of the National Bureau of Economic Research.

NBER working papers are circulated for discussion and comment purposes. They have not been peerreviewed or been subject to the review by the NBER Board of Directors that accompanies official NBER publications.

(C) 2021 by Patricia Cortés, Semiray Kasoolu, and Carolina Pan. All rights reserved. Short sections of text, not to exceed two paragraphs, may be quoted without explicit permission provided that full credit, including $\odot$ notice, is given to the source. 
Labor Market Nationalization Policies and Exporting Firm Outcomes: Evidence from Saudi

Arabia

Patricia Cortés, Semiray Kasoolu, and Carolina Pan

NBER Working Paper No. 29283

September 2021

JEL No. J21,J61

\begin{abstract}
In the last decade, Gulf countries have imposed hiring quotas to promote the participation of natives in the private sector and address high levels of unemployment, particularly among women and the youth. This paper explores how one such policy, Nitaqat in Saudi Arabia, affected the outcomes of exporting firms, the most productive sector of the non-oil economy. We find that whereas the policy was successful in increasing the employment of Saudi nationals by these firms, it came at a high cost. In the year following the announcement of the policy, relative to firms above the quota, firms below the quota were 1.5 percentage points more likely to exit the market, 7 percentage points less likely to export, and conditional on exporting, the value of their exports fell by 14 percent. Additionally, surviving treated firms reduced their labor force by 10 percent. We find that to comply with the policy, firms hired mostly lower-wage, low-skilled Saudis. The policy doubled the share of women in treated firms. Importantly, we find that these short-term effects persisted for at least three years after the policy's implementation.
\end{abstract}

Patricia Cortés

Questrom School of Business

Boston University

595 Commonwealth Avenue

Boston, MA 02215

and NBER

pcortes@bu.edu

Semiray Kasoolu

Y Analytics

semiray.kasoolu@gmail.com
Carolina Pan

Power for all

55 Ellery Street

Cambridge, MA 02138

carolina@powerforall.org 


\section{Introduction}

Countries in the Middle East have long relied on foreign workers for the production of goods and services in their economies. According to the International Labour Organization (ILO), the Gulf Cooperation Council (GCC) region hosts 10 percent of all migrants globally and has the highest proportion of non-nationals in the employed population (over 70 percent). In Saudi Arabia, home to the world's third-largest migrant population, by the end of 2019 more than three-quarters of the 13.4 million employed were foreign-born. ${ }^{1}$ The share of nonnationals employed is even higher in the rest of the Gulf. It exceeds 80 percent in Kuwait and Oman and reaches almost 95 percent in Qatar.

The prevailing social contract has been one through which governments redistribute oil rents by securing jobs for their nationals in the public sector, while foreign workers are employed in the lower-paying private sector, mostly in retail and construction. ${ }^{2}$ However, as the reliance on oil to provide subsidies for the local families in the form of government employment became unsustainable due to declining revenues, youth unemployment substantially increased, threatening the political stability of these countries. As a result, since the early 2010s, governments started to impose a series of nationalization programs on the labor force, with the objective of increasing native employment in the private sector. These policies generally came in the form of quotas for native hiring or taxes on foreign hiring by private firms. $^{3}$

The effects of these types of policies on firms' competitiveness — and thus overall labor market and national productivity outcomes - depend on a set of factors. Intuitively, any restriction on the hiring decisions of firms, without other policy changes, should make them worse off. The extent of the negative effects will depend on how foreign and native labor

\footnotetext{
${ }^{1}$ Source: GASTAT, based on GOSI and MCS data.

${ }^{2}$ The private sector has been historically undesirable for locals, for both cultural and financial reasons. Jobs in the public sector pay more and provide better non-wage benefits (pensions, shorter hours, more generous leave policies). Additionally, they are perceived as being of higher status, and are restricted to nationals (Saudis before 1984 were forbidden to work in the private sector). Many occupations in the private sector are seen as undesirable by natives because they are dominated by immigrants from less developed countries. See Al-Aali (2014) for a literature review.

${ }^{3}$ All GCC countries (Bahrain, Kuwait, Oman, Qatar, UEA and Saudi Arabia) have implemented a variation of a quota policy.
} 
compare in terms of price, ease of hiring, skills, and productivity. ${ }^{4}$ How firms react to the policy will ultimately determine its success. If firms can smoothly substitute native for foreign labor at a low or no cost, or to change their production technology relatively easily, the effect of the policy on costs and production decisions will not be large. However, if native labor is not a good substitute for foreign labor, or if it is much more expensive, then firms will adjust their operations, reduce their output and potentially exit the market. Furthermore, the policy may backfire if the Saudi employment gains are offset by other losses. If the negative effects on the firms are too large, then aggregate employment of natives might even shrink as many firms exit or reduce their size considerably.

In this paper, we study how a strict nationalization policy, the Nitaqat initiative in Saudi Arabia, affected non-oil private exporting firms' competitiveness. Our rich data allow us to look at a wide set of outcomes: firm exports, employment decisions (composition and size), labor costs, and exit rates.

We focus on exporting firms for a few reasons. First, exporter firms represent the "best" firms in an economy, and as such, are particularly important for the country's competitiveness and growth. Exporters tend to be significantly larger, more productive, more technology- and capital-intensive, to pay higher wages, and to use more skilled workers than their nonexporting counterparts (Aw and Hwang 1995; Bernard and Jensen 1999a; 1999b; Castellani 2002; Delgado, Farinas, and Ruano 2002; Melitz 2003; Bernard, Jensen, and Schott 2006). ${ }^{5}$ Second, for the particular case of Saudi Arabia, non-oil exporting firms' performance is of significant policy relevance. The Saudi government has declared in its long-term growth plan (Vision 2030) as one of its strategic goals to "raise the share of non-oil exports in non-oil GDP from 16\% to 50\%.” ${ }^{6}$ Finally, we have access to a novel dataset that includes all export transactions in the Kingdom between May 2006 and June 2016.

\footnotetext{
${ }^{4}$ It will also depend on the elasticity of demand, i.e. the extent to which firms can pass along higher costs to consumers.

${ }^{5}$ Note that whether exporting firms are more or less affected by Nitaqat than non-exporting firms is unclear ex-ante. On one hand, we expect these firms to be more resilient to labor cost increases: i.e. that their specific characteristics, such as higher productivity, allow them to better absorb the shock than non-exporters. On the other hand, though, since exporters are price takers and cannot pass the price increase to consumers they might be worse hit than nonexporters.

${ }^{6}$ The Vision 2030 document is found here: https://www.vision2030.gov.sa/media/rc0b5oy1/saudi_vision203.pdf
} 
To estimate the effects of Nitaqat on exporting firms, we take advantage of the policy design that sets a threshold for the minimum share of Saudi workers in a firm. There is one threshold per combination of industry and firm size, and it is set such that slightly more than half of the firms in the bin are below it. Those below the quota face strong restrictions in their ability to hire foreign workers and are therefore compelled to change their labor force composition to keep operating. Our main empirical strategy is a simple difference-indifference analysis comparing the one-year change in outcomes between firms above and firms below the threshold.

Our main empirical strategy identifies short-term causal effects as long as the firms above the threshold provide a valid counterfactual for changes in the outcomes for firms below the threshold in the absence of the policy. We provide suggestive evidence that this is indeed the case by conducting an event study (pre-trends) analysis of key outcomes.

Our results suggest that the policy had a short-term negative effect on competitiveness as we find evidence that the probability of exiting the market increased for firms below the threshold relative to those above, the probability of exporting decreased conditional on staying in the market, and the value and volume of exports declined for those who continue exporting. Total exports per worker did not change significantly or might have even decreased. These results, combined with an increase in the wage bill due to a change in the composition of employment, suggest that the policy was very costly for firms and eroded their competitiveness. The mechanisms behind this outcome are the following. Whereas the policy succeeded in encouraging firms to increase the share of Saudis in the private sector, this was achieved by both increasing Saudi hiring and reducing ex-pat employment. Firms decreased the number of foreign workers disproportionately, resulting in a smaller total number of employees per firm. Using data on wages, we find that the wage bill for firms below the threshold increased as Saudi wages are much higher than foreign wages. We also find that the average wage for Saudis decreased, suggesting that Saudis hired as a result of the policy were lower paid. Firms below the threshold increased the share of Saudi females in their workforce, suggesting that the policy had a positive effect on increasing the labor force participation of women. The effect on female hiring is particularly large: we find that the policy led to firms below the threshold to more than double the share of women in their labor force. 
Overall, these short-term effects suggest that firms adapted rapidly to the implementation of the policy. One year after the policy, more than 60 percent of firms below the threshold had crossed it. To study if this rapid adjustment had medium-term consequences on exporting firms, we extend our analysis to include a few more years into the future. Our estimates suggest that these short-term effects persisted - three years after the policy announcement, firms below the threshold at baseline were relatively less likely to export, had fewer employees, lower exports, higher wage bills, and a larger share of women in their labor force.

To complement our main empirical strategy, we present specifications that exploit variation in the distance between the firm's observed Saudi share and the quota. We find that within treatment status, firms with a relatively low share of Saudis at baseline reacted more strongly to the policy, but that the reaction was significantly stronger for firms below the threshold. In other words, we identify a change in the slope in the relationship between distance and outcomes at the quota level. These results confirm that Nitaqat imposed significant constraints on exporting firms, particularly for those with very low Saudi shares on the baseline. Finally, we compare the effects on exporting firms with the effects on nonexporting firms. In support of the hypothesis that exporter firms are more resilient, we find that they were able to adapt more successfully to the policy - in particular, they hired Saudis at a higher rate, their total labor force declined by less, and their wage bill did not increase as much. These results, combined with the negative effect of Nitaqat on the value of exports, strongly suggest that the output for non-exporters is likely to have decreased as well.

Our paper contributes to two strands of the literature. The first is the literature on immigration and its effects on the host country. Most of this literature has focused on immigration inflows' impact on the labor market outcomes of natives (see Dustmann et al (2016) for a recent survey). Our analysis, on the other hand, is at the firm level and focuses on the effects of immigration restrictions on productivity and how firms adapt to them. A handful of papers have explored how firms and production decisions are affected by immigration flows. Ottaviano and Peri (2018) study the impact of immigrants on the imports, exports, and productivity of service-producing firms in the U.K. They find that immigrants increase the overall productivity of firms, reduce country-specific offshoring and increase country-specific 
exports. Clemens, Lewis, and Postel (2018) study what happened to native employment and production when the Bracero Program, which allowed foreigners to work in agriculture in the US, was abolished. They find that restrictions on immigration did not increase the employment or wages of natives and that firms adapted by developing new technologies. Lewis (2011) looks at how low-skilled immigration flows affected technology adoption. His results suggest that plants in areas with heavy flows of low-skilled foreign workers adopted significantly less machinery per unit of output. The results imply, as in Clemens, Lewis, and Postel (2018), that changes in production technology reduce the effect that immigration has on less-skilled relative wages and employment.

The second strand of the literature that our paper relates to is employment quota and affirmative action programs. Most of these studies have focused on the effect of these policies on workers (see Holzer and Neumark (2000) for a survey, Chay (1998) on African Americans in the US, and Howard and Prakash (2012), Chin and Prakash (2011), and Prakash (2009) for Indian Minority Hiring quotas.) There are a few studies that look at nationalization policies in the GCC countries. Hertog (2014) reviews the different Gulfization policies, with a specific focus on the ones that involve taxes and subsidies to close the gap between the cost of hiring nationals and migrant workers. He finds that micro-interventions fail to solve the high unemployment problem as they are costly and not performed in a systematic way. Ramady (2013) discusses the tradeoff between higher (but costlier) Saudi employment in the Saudi private sector and describes how economic growth and productivity could be affected if additional labor market restrictions (like a Saudi minimum wage) are applied. Sadi (2013) ran a survey to identify the main costs and benefits of Nitaqat to the Saudi private sector business owners. While there was optimism about the program's success in general, most employers admitted to hiring Saudis just to fill quotas.

The closest studies to ours are Peck (2017) and Miller, Peck, and Seflek (forthcoming). As in our paper, Peck (2017) looks at the effect of Nitaqat on the exit of firms and the total employment at the firm level and finds similar results. Our paper extends her study in three important ways. First, we focus on the export sector, where we have measures of output and 
productivity. ${ }^{7}$ Having these outcomes allows us to provide more direct evidence of the unintended costs of the policy, and thus its overall performance, particularly for a set of firms who are key for the country's competitiveness and growth. Second, using these variables, combined with data on wages, we can explore the relative productivity and cost of hiring foreign vs. Saudi labor. Third, we take advantage of a longer time series and expand the period of analysis to evaluate the persistence of the short-term effects. Fourth, we look at changes in the gender and education composition of employment in the surviving firms to learn about the type of Saudis hired to comply with the policy. Miller, Peck, and Seflek (forthcoming) also find that Nitaqat led to a dramatic increase in female employment. The authors argue that the need to hire more Saudis induced firms to incur the fixed costs of gender integration.

The rest of the paper is organized as follows. The next section describes the background and context that led to the introduction of the policy; section 3 describes our data sources and presents descriptive statistics; section 4 lays out our empirical specifications and tests, and section 5 concludes.

\section{Background}

Saudi Arabia has been a net importer of labor for much of its history. The inflows of foreign labor increased massively during the oil boom of the 2000s, mostly to serve the new large infrastructure developments. Combined with a social contract of oil wealth redistribution through government employment, this generated a dual labor market with Saudis concentrated in the public sector and non-Saudis dominating the underdeveloped, lowwage, and non-tradable private sector. As of Q2 of 2019, 75 percent of the employed population was foreign, who in turn represent over 80 percent of workers in the private sector. Saudization, the increase in Saudis' employment share in the private sector, has been a government objective since the 1970s. This goal has been translated into active labor market policies since 1995, but they were not strictly enforced until 2011 when the Arab Spring added urgency to them.

\footnotetext{
${ }^{7}$ The focus on exporting firms somewhat ameliorates concerns about violations of the stable unit treatment values assumption, as they also compete with firms abroad and are, therefore, less affected by spillovers from treated domestic firms.
} 
With about a quarter of the Saudi population between 15 and 29 and high youth and female unemployment, ${ }^{8}$ the government urgently designed redistribution measures in the aftermath of the Arab Spring. These included a massive housing subsidy program, unemployment benefits of SAR 2,000 per month for a year, ${ }^{9}$ and an increase in wages and jobs in the public sector. The government also put into effect stricter nationalization measures to incentivize private sector firms to hire Saudis. The Ministry of Social Development and Labor implemented Nitaqat (“bands” in Arabic) in 2011, a program that assigned Saudi hiring quotas for firms based on their industry and size. Firms were divided into 45 main economic activities and five size categories: micro (<10 employees), small (10-49), medium (50 to 499), large (500 to 2999), and giant (3000+). Micro firms were, in the beginning, exempt from the policy.

Within combinations of industry and firm size, three thresholds of Saudi shares were determined to classify firms into 4 color bands: red, yellow, green, and platinum. The key threshold is between yellow and green, as firms above it are rewarded, and below it are subject to sanctions. This threshold was chosen so that a little more than half of the firms were below it, and the other two cutoffs were chosen in a more ad hoc fashion. It is important to note that this led to significant variation in quotas across and within sectors. As an example, below are the bands for the Wholesale and Retail Industries:

\begin{tabular}{|l|l|l|l|l|}
\hline & Small & Medium & Large & Giant \\
\hline Red & $0-4 \%$ & $0-4 \%$ & $0-9 \%$ & $0-9 \%$ \\
\hline Yellow & $5-9 \%$ & $5-16 \%$ & $10-23 \%$ & $10-24 \%$ \\
\hline Green & $10-26 \%$ & $17-33 \%$ & $24-34 \%$ & $25-36 \%$ \\
\hline Platinum & $27 \%+$ & $34 \%+$ & $35 \%+$ & $37 \%+$ \\
\hline
\end{tabular}

The main source of benefits and costs for the different bands is the ability to access foreign labor. The policy mechanism for that was the speed and flexibility in the issuance of visas for foreign workers. Firms in the green and platinum bands could use new online

\footnotetext{
8 The female unemployment rate reached a historic high of 34 percent in 2006 and is currently just below 30 percent. Youth unemployment rates have oscillated between 25 and 30 percent for more than a decade.

9 The exchange rate as of November 2020 is of 3.75 Saudi Riyals per US dollar.
} 
services for visa renewal and issuance and could also freely hire foreign workers from the red and yellow bands. ${ }^{10}$ Firms in the yellow band could not use electronic visa services and faced some restrictions on their issuance. Firms in the red band could not renew their existing visas or apply for new ones. Additionally, they could not open any new branches or facilities.

The purpose of these restrictions was to incentivize firms to increase their hiring of Saudi workers by making staying in the red band inviable. Starting in October 2012, the policy also imposed certain requirements for what constitutes a "full" Saudi job. The position had to pay a salary of at least 3,000 SAR per month (around 3.5 times more than the median wage of ex-pats), imposing an effective de facto minimum wage for Saudi employees. ${ }^{11}$ The government supports up to 50 percent of the Saudi salaries for the first 2 years of their tenure, up to a maximum of 2000 SAR through the Human Resource Development Fund (HRDF). Moreover, the policy incentivized the hiring of certain demographics, prisoners and disabled Saudis, for example, by counting their job as a multiple for Nitaqat.

The Nitaqat policy measures the nationalization performance of companies by calculating, over successive periods of 13 weeks, a moving average of the share of Saudi nationals employed by a firm. The policy was announced in July 2011 and the government started implementing the sanctions in September of the same year. ${ }^{12}$ Enforcement was rigorous since the very beginning, as both the Ministry of the Interior and the social security agency updated visa records weekly.

The program is still in place but underwent several modifications over time. In 2013, under increasing pressure to raise non-oil government revenues, the government introduced

\footnotetext{
${ }^{10}$ The ability of green and platinum firms to hire workers from yellow and red firms might be problematic for the validity of the assumption that the outcome for one firm does not depend on the treatment status of other firms. We observe, however, very small flows of foreign workers across firms between 2011 and 2012. Less than 2 percent of non-Saudi workers switched firms between these two years and of those, 28 percent switched from a firm below the threshold to a firm above the threshold. In comparison, 13 percent of Saudis switched firms, and close to 20 percent of them moved from a yellow or red firm to a green or platinum one. Unfortunately, we cannot compare 2011-2012 to 2010-2011 foreign flows, as before Nitaqat non-Saudi workers were not allowed to switch firms without the permission of the business owner that hired them originally.

${ }^{11}$ Even before the imposition of the minimum wage, ex-pats earned much less than Saudi nationals. In 2011, the median salary for Saudis was 3.3 times the median salary for immigrants. Controlling for detailed occupational categories reduces the gap to a still very sizeable $89 \%$.

${ }^{12}$ More specifically, starting on September 11, 2011, firms in the red and yellow bands could not renew visas for longer than three months, faced restriction on visas for new workers (no new visas for firms in the red band and one visa for every two workers departing the country for the yellow firms), and those in the red band could not open new facilities or branches. From November 2011 (February 2012) firms in the red (yellow) band could no longer renew visas for their employees.
} 
an annual ex-pat levy of 2400 SAR per foreign worker above a 1:1 ratio of ex-pats and Saudis. In early 2014, the micro firms were included in Nitaqat, with the requirement that they employ at least one Saudi national. In 2017, quotas were significantly tightened and new color bands (i.e. light green, medium green, dark green) were created. ${ }^{13}$ Our paper studies the effects of Nitaqat 1.0, the first version, announced in mid-2011. Our first analysis focuses on the short-term effects (between 2011 and 2012); this is the only period with no other overlapping policies making it ideal to estimate causal effects. We then move to a longer time horizon to explore the mid-term effects of the policy, under the caveat, however, that other policies were also affecting firms’ decision making.

\section{Data and Descriptive Statistics}

We make use of three main datasets, all provided to us by the Saudi government. The datasets provide firm-level data on Nitaqat performance (Nitaqat dataset), job spell, and demographic characteristics of workers (General Organization for Social Insurance (GOSI)), and exporting firm characteristics (Customs dataset). We merged these datasets and constructed a panel of firms containing all the relevant characteristics before and after the program was implemented. ${ }^{14}$ We use all three datasets to investigate the effect of the policy on exporting firms and compare these effects to all firms from the first two datasets.

Nitaqat

The Ministry of Labor gathers administrative data weekly to follow the evolution of the program and administer rewards and penalties. The data series starts in June 2011, when the quotas were introduced and firms were given their initial ratings. The firm-level data primarily tracks the number of employees by nationality and includes the band color of a firm at a given point in time. It also contains data on the geographic location of the firm and its

\footnotetext{
13 Another policy that might have affected a few exporter firms is the Retail Sector Decree, implemented in 2012. The decree mandates that stores only employ Saudi women in shops that sell merchandise of primary interest to women (EPoD, 2015).

${ }^{14}$ We match close to 80 percent of exporting firms to Nitaqat and close to $70 \%$ to both Nitaqat and GOSI. Appendix Table 1 compares mean values of exporting variables for all firms in the dataset vs. for firms in the matched sample. We see positive selection into the matched sample, suggesting that our estimates might underestimate the true effects.
} 
main industry. We will use these data to construct the treatment indicator variable, test the effects of the Nitaqat policy on employment by nationality, and survival rates.

\section{GOSI}

The Saudi General Organization for Social Insurance (GOSI) collects data on each job spell in the economy, covering the entire private sector and some public sector workers subject to the social insurance rules and regulations, such as those working for state-owned enterprises (SOEs). We were provided with the administrative records between 2009 and 2016. The GOSI data is very granular (at the job contract level) but can be easily aggregated to the individual or firm level. It includes basic demographic characteristics of each individual (gender, nationality, age, place of residence, education level) and characteristics of their job, such as occupation, wage, and the firm they work for.

\section{Customs Data}

The customs data is our most novel dataset, and to our knowledge, this is the first study that exploits it. It was provided by the Ministry of Economic Planning and includes all export transactions in the Kingdom between May 2006 and June 2016. The data is at the transaction level: it records transactions for each exporting firm, its export product, export market, the quantity of export, value of export, and date of transaction. We aggregate the data at the firm and year level ${ }^{15}$ and focus only on non-oil exporting firms. ${ }^{16}$

Table 1 presents summary statistics for exporting and non-exporting private firms in Saudi Arabia that were operating in 2011. We include non-exporting firms to illustrate how exporting firms compare to the rest of the economy. Exporter firms represent a small share of firms in the Kingdom, around 1 percent of all firms and 11 percent of manufacturing firms, compared to exporting firms representing 35 percent of US manufacturing (Bernard et al, 2018). Despite representing such a small share of firms, non-oil exports account for close to 17 percent of Saudi’s GDP.

\footnotetext{
${ }^{15}$ Note that many firms report making shipments just a few times a year. In our sample, 17 percent of firms report one shipment in a 12-month period (conditional on exporting in the following 12-month period), and another 20 percent fewer than five. Because of this, we cannot construct higher frequency data.

${ }^{16}$ We exclude oil exporting firms as they are state-owned.
} 
Overall, we observe 1255 exporting firms, and close to 160,000 non-exporting firms in our dataset. Exporting firms are much larger than non-exporters firms. In particular, there are much fewer exporting firms in the micro category - only about 10 percent, which is much lower compared to non-exporting firms, 60 percent of which have fewer than 10 employees. Almost half of exporting firms are medium-sized while that share is only five percent of nonexporting firms. Overall, conditional on having more than 10 employees, the average size of exporter firms is 420 compared to just 55 of non-exporting firms. Export firms have a larger Saudi employment share than non-exporting firms - 19 vs. 7 percent. They are also much less likely to be below the Nitaqat threshold, suggesting that they rely much less on foreign labor compared to non-exporting firms in the same industry and of the same size range. In fact, about 80 percent of non-exporters are below the quota (red or yellow bands) compared to 60 percent of exporting firms. The exit rate for exporting firms is close to half of the exit rate for non-exporting firms (1.1 vs. 2 percent). In terms of geographic distribution (not shown in the table), exporters are more concentrated in the largest regions of Riyadh and Makkah.

\section{Empirical Analysis}

In choosing an empirical approach we faced a trade-off between having enough power to identify reasonably sized effects and having a clean(er) identification. The natural strategy to follow, given the structure of the policy, would have been regression discontinuity design (RDD) or regression kink design (RKD). Unfortunately, power calculations showed that because of our small sample size, we would not be able to identify even relatively large effects. ${ }^{17}$ We, therefore, chose as our main empirical strategy a simple difference regression that compares changes in outcomes between firms that were over the threshold to those below the threshold for a green band classification when the policy was announced in July 2011.

\footnotetext{
${ }^{17}$ We use the Stata command rdpow to do power calculations (Cattaneo et al, 2019). We set the treatment effect at the magnitude we find in our diffs-in-diffs estimations, use a uniform distribution kernel and the optimal bandwidth estimated by the command rdbwselect (Calonico et al, 2014), and select a local polynomial of order one to construct the point estimator. The calculations suggest that power will be somewhere between 10 and 15 percent for our two main outcomes, total employment and value of exports.
} 
To address concerns about underlying differences between firms above and below the threshold, we use three different strategies. First, we show specifications in which drop firms from the platinum band, arguably extraordinary firms. ${ }^{18}$ Second, following Crump et. al (2009), we discard all observations with estimated propensity scores outside the range of 10 to 90 percent and thus, restrict our comparison to firms that look more similar ex-ante. We calculate the propensity score using the following baseline variables: sector, size, and region fixed effects, (log) total export value, and (log) total number of employees in 2011. Finally, we provide evidence of parallel trends in section 4.3.

To complement our diffs-in-diffs strategy, in section 4.4, we present models that exploit variation in the distance between the firm's observed Saudi share and the threshold for the green band. However, as we are testing for differences in slopes, we are underpowered, and sometimes our estimates are not precisely estimated.

Before moving to the econometric specification, it is helpful to look at the characteristics of firms that were below the threshold (treated firms) and compare them to those above the threshold (control firms). As observed in Table 2 and as expected given that the Saudi share in firms is not randomly allocated, exporting firms below the threshold are on average different than those above the threshold in important dimensions: the value of their exports is significantly lower, they hire fewer Saudis, more foreigners, and have somewhat larger labor forces (difference not statistically significant). Smaller differences are found in the main sector of operation and geographic location (not shown in the table).

Panel B of Table 2 focuses on the subsample that excludes platinum firms. We find much smaller differences between firms above and below the threshold, particularly for the value of exports.

\subsection{Differences-in-Differences Specification}

To identify the short-term effects of Nitaqat on exporter firms we compare 12-month changes in our outcomes of interest between exporter firms below and above the threshold.

\footnotetext{
${ }^{18}$ The differences in Saudi share between green and platinum firms is 30 percentage points, whereas the difference
} between green and yellow firms is 6 percentage points, and between yellow and red firms is 5 percentage points. 
We focus on the difference between July 2011 and July 2012. Our main econometric specification is the following:

$$
\Delta Y_{i j r s}=\alpha+\beta * \text { Below }_{i j r}+\pi_{j}+\pi_{r}+\pi_{s}+\varepsilon_{i j r s}
$$

where $i$ is for firm, $j$ is for industry group, $r$ is for region, and $s$ is for firm size. $Y_{i j r s}$ are firm outcomes. Below is a dummy variable equal to one if the firm was assigned yellow or red Nitaqat bands in July 2011. The coefficient of interest is $\beta$, while $\pi_{j}, \pi_{r}$ and $\pi_{s}$, stand for industry, region, ${ }^{19}$ and size fixed effects.

We focus on three sets of outcomes: (1) labor composition and size of the firm's labor force, (2) export outcomes, and (3) labor costs. We present specifications that vary the controls that are included and sample restrictions.

We start by studying the most direct objective of the policy: Saudization rates (see Table 3). ${ }^{20}$ In all specifications, the coefficient of the Below dummy is positive, as expected, and statistically significant. Firms below the threshold, those facing penalties for having relatively too few Saudi workers, increased the relative size of the Saudi workforce in their firms. The magnitudes of the coefficients suggest that these firms increased the share of Saudis in their workforce by around 7 percentage points compared with the control firms. ${ }^{21}$ This represents a large change, as the average Saudi employment share for exporting firms is close to 20 percent. The estimates for the sample excluding platinum firms are smaller but still sizeable and statistically significant. So far, these results strongly suggest that, at face value, Nitaqat was successful since it led exporting firms to significantly increase the share of Saudis in their workforce. Firms that were below the quota in 2011 had to increase their Saudization ratios to keep operating in 2012. This is not surprising as the program was strictly enforced, with severe penalties for non-compliers.

\footnotetext{
${ }^{19}$ We code region as Riyadh, Makkah, and other.

${ }^{20}$ Employment outcomes are calculated conditional on firm survival. We find a negative effect on the probability of survival (see Table 4), but is very small in absolute terms.

${ }^{21}$ This sizeable change guaranteed that close to $60 \%$ of treated firms had crossed the threshold within a year of the policy’s implementation. See Appendix Figure 1.
} 
The next two outcomes (rows), changes in the (Log) number of Saudis ${ }^{22}$ and foreigners hired by firms, explore the mechanisms through which the higher Saudization shares were attained. We find that they were driven by both increasing Saudis and decreasing non-Saudis. Specifically, relative to firms above the threshold, firms that were below the threshold increased the number of Saudi employees by close to 35 percent across both samples. Firms below the threshold reduced the number of foreign workers by 14-15 percent (all bands) and 11-12 percent (excluding platinum firms). The increase in the number of Saudi employees does not fully offset the reduction in the number of foreign workers, so on average, firms below the threshold saw a decrease in the total number of workers by around 6-7 percent (all bands) and 4-6 percent (excluding platinum firms).

Table 4 presents the main outcomes of interest: the effects of Nitaqat on exports and productivity. The first row presents the coefficients for the probability of having exited the market by mid-2012. We find that Nitaqat led to an increase of around 1.5 percentage points in the probability of exiting the market, with three out of the four coefficients marginally significant. Although the magnitude is not large in absolute terms, it represents an increase of more than 100 percent over the baseline value for the control group. In the row below, we find strong effects of Nitaqat on the probability of exporting, conditional on firm survival: firms below the threshold are about 7 percentage points more likely to stop exporting between 2011 and 2012. ${ }^{23}$ This impact on the probability of exporting might have further negative consequences in the longer term on firms, as exporting helps firm performance (Park et al, 2010). Among firms that continue to export and for the sample of firms that includes all bands, firms below the threshold reduce their exports (measured in millions of SARS) by about 11-13 percent compared to firms above (the coefficient is marginally significant in the specification with no fixed effects and more noisily estimated when the fixed effects are added). For the sample excluding platinum firms, the coefficients are smaller and with larger standard errors, but the magnitude is economically sizeable. We find similar effects when we

\footnotetext{
${ }^{22}$ A concern with the reported numbers for Saudi Employment is that firms might hire "ghost" workers to meet the thresholds. We have no way of directly testing if a worker is being paid for meaningful work, but note that Miller et al (forthcoming) find little evidence that the share of workers likely to be used on paper to comply with the policy (those showing little wage growth, and who do not change jobs or occupations) changed drastically after Nitaqat or that its increase was more noticeable for women.

${ }^{23}$ These two results are not inconsistent, as a firm might not exit the market but stop exporting. Note that this is consistent with exporting firms being able to pass on higher costs to their domestic consumers, but unable to increase export prices.
} 
measure exports in volume, although again our estimates for firms excluding platinum firms are not statistically significant at conventional levels. Note that a decline in exports does not follow directly from the reduction in the labor force, as Nitaqat affected labor composition, and there might be productivity differences between Saudi and non-Saudi workers.

Finally, the last rows show the effect on exports per worker. The coefficients are all negative and large (particularly when measured using export volume) but not statistically significant. ${ }^{24}$ With the caveat that the coefficients are not precisely estimated, the finding of a negative effect of productivity per worker suggests that Saudis are likely to be less productive than non-Saudi workers, or at least not more productive.

Finally, GOSI data from the social security administration allow us to do a deeper analysis of the changes experienced by exporting firms and their coping strategies with Nitaqat policy. In particular, we study how Nitaqat affected firms' costs, in particular their wage bill, and the gender and skill composition of their labor force. Using aggregated data from GOSI at the firm-year level, we construct the total amount paid to workers during the month. We combine these data with the number of Saudi workers in a month to construct a measure of the average salary of Saudi workers. The coefficients in the first row of Table 5 suggest that firms below the threshold increased their wage bill by around nine percent, despite reducing the size of their workforce. This is not surprising given that firms substitute some of the foreigners with Saudis, who are paid a much higher wage on average. The row below presents the results on average wages for Saudis paid by exporting firms. We find strong evidence of a decrease in the average wage of Saudis by around four percent, suggesting that firms below the threshold hired lower-wage and presumably lower-skilled Saudis, to conform with Nitaqat requirements. We confirm that firms below the threshold increased their hiring of low-skilled Saudis (those with at most a high school education) substantially, and to a much lesser extent increased their hiring of high-skilled Saudis relative to firms above the threshold. The final outcome we explore is the share of females in the firm's Saudi labor force. Our results suggest that the policy had a positive effect in getting more women to work in the Saudi exporting sector. The magnitude of the coefficients suggests a more than double increase in the share of women, relative to the baseline share for

\footnotetext{
${ }^{24}$ Note that the magnitudes of the coefficients are as expected, given the estimated decline in the labor force and the larger decrease in total exports.
} 
control firms. This is an important finding as Saudi Arabia struggles with low levels of female labor force participation (particularly in the export sector as seen in Table 1) and high levels of female unemployment.

\subsection{Event Study Analysis}

In this section, we present suggestive evidence on the validity of the key identifying assumption of our design — firms above and below the Nitaqat threshold experienced similar trends in the main outcome before the implementation of the policy. If this is the case, then, the firms above the threshold would be a good counterfactual for the firms below the threshold. We also extend the period of analysis to cover more years after the policy implementation to examine longer-term effects.

Data availability restricts the types of pre-trend tests we can perform. In particular, the Nitaqat data on employment was collected for the implementation of the policy, and thus, lacks information for the preceding period. We do have data for a few previous years on exports from the Customs dataset, and data since 2009 from GOSI.

Figure 1 presents the raw data for the value of exports for a balanced sample. As observed, and noted before, characteristics of firms above and below differ in levels. However, they are much more similar when trends are considered. In Figure 1, firms both below and above the threshold see their exports decrease between 2008 and 2009, and increase between 2009 and 2011. However, between 2011 and 2012, after the policy was implemented, the trends start to diverge, with a clear decline between 2011 and 2013 for firms below the threshold, and an increase for firms above. The trends are again similar between 2013 and 2014, but the gap between export levels at the end of the period is much larger than it was in 2011.

Figure 2 presents the time-series for GOSI outcomes, by treatment status. Before the implementation of the policy, firms below and above the threshold trend in similar ways, and this is true across all the different outcomes. However, in 2012, relative to firms above, treatment group firms experienced a larger increase in all outcomes, particularly for the number of low-skilled Saudis and the female share of the Saudi labor force. As with the export outcomes, trends look more similar again between 2013 and 2014. 
For a more rigorous analysis, we compare treatment effects by year. More specifically, we estimate the following model:

$$
Y_{i t}=\alpha_{i}+\beta_{t} * \sum_{t} \text { Below }_{i} * I(\text { Year }=t)+\pi_{t}+\varepsilon_{i t}
$$

where $\alpha_{i}$ are firm fixed effects and $\pi_{t}$ year fixed effects.

Figure 3 shows the estimates for the betas and their 95 percent confidence intervals (standard errors are clustered at the firm level) when the outcome variable is the value of exports. The left panel includes all firms in the sample, the right panel is limited to a balanced sample. As observed, there are small and not statistically significant differences between the log of export value between firms above and below the threshold in the years before the implementation of the policy relative to their value in 2011. In Panel A, we estimate a large coefficient for 2012, similar in magnitude to that in Table 4 Column (1), but no quite statistically significant at conventional levels. We estimate slightly larger coefficients for 2013 and 2014 (statistically significant at 10\% level), suggesting that the short-term effect of the rapid adjustment persisted over time and might have even worsened. We observe similar results in Panel B when we focus on a balanced sample, except for the much smaller coefficient for 2012. A potential explanation for the lag in the effect on export value for firms that continue to export is that export commitments are longer-term.

Figure 4 presents the coefficients of equation (4) for GOSI outcomes based on a balanced panel of firms. ${ }^{25}$ We find small and not statistically significant coefficients for 2009 and 2010, matching the parallel trends we observed in Figure 2. As with exports, we find that the effects of Nitaqat persisted at least for a few years after the announcement of the policy. Although not definite, these exercises provide some evidence that our empirical estimates are capturing causal effects.

We cannot test for parallel pre-trends for Nitaqat related outcomes, but we can still explore the persistence of the short-term effects. Table 6 presents the estimation of equation (2) for the probability of exiting the market and of exporting conditional on surviving, for the

\footnotetext{
${ }^{25}$ Note that our GOSI data starts in 2009.
} 
Saudi share, and for Saudi, Foreign and Total employment. ${ }^{26}$ Once again, we find strong persistence of the short-term effects. Moreover, for foreign and total employment the estimates suggest a subsequent widening of the effects. Remember, however, that other policies were operating in the last years, so we cannot have full confidence that Nitaqat is the main driver of the additional effects observed from 2013 to $2015 .^{27}$

\subsection{Alternative specification}

We complement our diffs-in-diffs strategy with specifications that exploit variation in the distance of the share of Saudis in a firm's labor force to the threshold for the green band. The nature of the Nitaqat policy implies that the treatment intensity depends on the distance to the threshold, even within bands. This is because the farther below a firm is from the minimum Saudi share needed to be in the green band, the more constrained its choices are if the firm wants to move bands. Additionally, even for firms that are above the threshold, they might also face binding constraints in reducing the number of Saudi workers, although they do not have incentives to increase it. Our hypothesis is, thus, that there will be a change in the slope of the relationship between an outcome variable and distance at a distance of zero, but that the slope is not necessarily zero to the right of the threshold.

Appendix Figure 2 shows the distribution of the distance variable defined as

$$
\text { Share Saudi } \text { Sijs }_{-}-\text {Threshold }_{j s}
$$

where $i$ is for firm, $j$ is for industry group, and $s$ for firm size, for the sample of all firms. Most firms are clustered around the threshold, but we still observe significant variation in distance, both above and below the threshold. The distribution is skewed to the right because threshold values have a maximum well below one.

Our econometric specification is as follows:

$$
\begin{gathered}
\Delta Y_{i j r s}=\alpha+\beta * \text { Distance }_{i j r s}+\partial * \text { Distance }_{i j r s} * I\left(\text { Distance }_{i j r s}<0\right)+\pi_{j}+\pi_{r}+ \\
\pi_{s}+\varepsilon_{i j r s}
\end{gathered}
$$

\footnotetext{
${ }^{26}$ We extend our period to include data for 2015. Our Nitaqat regressions use firms that appear in the dataset for the whole period. We do not include 2015 in the estimations presented in Figures 3 and 4 because it will decrease our balanced sample's size even more, and our estimates are already quite noisy.

${ }^{27}$ Our results are robust to including an interaction of baseline share Saudi (or Log of Foreign Employment) with a linear trend to account for the implementation of the ex-pat levy in 2013.
} 
As before, we restrict the sample to firms with a propensity score between 10 and 90 percent.

We illustrate our specification's idea in Figure 5, where we graph a bin-scatter of distance vs. our most direct policy outcomes and fit a linear function at each side of the threshold. A few observations stand out. Take for example Saudi Employment, not only was the average change in the Log of Saudi Employment much larger for firms below the threshold, within firms below and above, firms with relatively more constraints experienced higher employment growth, and the relationship is steeper for firms below the threshold. For all other outcomes, the slope of the lines is of the expected sign, although the change in slope at the threshold is not as stark.

Table 7 presents specifications with controls and standard errors and expands the set of outcomes. Generally speaking, coefficients for the direct effect of distance and the interaction are of the expected sign, and many are statistically significant. In particular, we find much steeper relationships within the treatment group for the Saudi Share, Saudi employment (aggregate and by skill), and female share. The interaction coefficients for the value of exports is not of the expected sign, but it is relatively small and not statistically significant.

Overall, this set of results complements the diffs-in-diffs results by providing a richer description of how Nitaqat affects firms with different initial concentrations of Saudi workers.

\subsection{Comparison with the effects on non-exporter firms}

Did exporter firms adapt differently to Nitaqat compared to non-exporter firms? The answer is not clear ex-ante. We expect exporter firms to be better firms, and thus to be more capable to absorb the shocks. On the other hand, they have less market power, and a lower ability to pass the increase in costs to consumers. Table 8 presents models that include both exporter and non-exporter firms and allow the coefficient on the Below indicator to vary between the two types of firms. ${ }^{28}$ Our specifications include interactions of all fixed effects with an exporting firm (at baseline) dummy. We present specifications with the full sample and with the sample dropping platinum firms. Generally, we find that exporter firms below the threshold were able to adapt better to the policy. Unintended negative effects, such as

\footnotetext{
${ }^{28}$ Note that we are not arguing for causality, in other words, we are not stating that it is exporting itself what drives the difference between the two types of firms.
} 
lower total employment and higher wage bills, were smaller for treated exporter firms. At the same time, they hired relatively more Saudis, both high and low-skilled, and the increase in the female share was particularly large. ${ }^{29}$

The more pervasive effects of the policy on the labor force size and costs of the nonexporter firms, combined with our estimated negative effect on exports for exporter firms, suggest that the output of the surviving non-exporter firms is likely to have been negatively affected as well.

\section{Conclusion}

Nationalization policies, and specifically Nitaqat, intend to increase Saudi employment in the private sector, which Saudi citizens have consistently avoided to either pursue or queue for higher paid jobs with better working conditions in the public sector. Our analysis shows that the policy increased the number of Saudis working in the exporting sector, but that this achievement came at a significant cost for the firms, as well as for the competitiveness of the economy as a whole. To explore the unintended consequences of the policy we analyze firm outcomes in the most productive sector of the Saudi economy - exporting firms. We find that firms below the quota threshold were 7 percentage points less likely to export. For firms that continued to export, export value decreased by around 14 percent and export volumes by 20 percent. Estimates of the effects on productivity per worker are large and negative but not statistically significant. These pervasive effects on exporting firms suggest that the long-term goal of the Saudi government of increasing the GDP share of non-oil exports is compromised by policies encouraging firms to hire more Saudi nationals through quotas and levies.

Our results also provide evidence on the relative quality of Saudi and foreign workers. In particular, our findings suggest that Saudi workers' higher salary was not close to being compensated by higher worker productivity - if anything, our estimates point to a decrease in productivity per worker. To comply with the quotas, firms seemed to have increased the hiring of low-paid, low-skilled Saudi workers. This result suggests that, unlike what Miller (2017) found in his study on affirmative action regulation for employment in the US, the low

\footnotetext{
${ }^{29}$ Our results for non-exporter firms are very similar to those in Peck (2017)’s Table 5, both in terms of sign and magnitude, but for exit rates. Note that she studies changes between July 2011 and October 2012, whereas we focus on the one-year change.
} 
representation of Saudis in the private sector is not due to high fixed costs in identifying highquality workers.

Our analysis focuses on the short to medium term - we look at changes one to four years after the implementation of the policy. A longer-term analysis will uncover other adjustment mechanisms implemented by firms. For example, one such mechanism could be changes in technology to lower the need for the now more expensive labor input in favor of more capital (see Lewis 2011 and Clemens, Lewis and Postel, 2018). Additionally, better information about the skills the private sector needs might lead to more productive human capital investments by the Saudi youth. Skills mismatch has been identified as one of the main drivers of the low productivity of the Saudi labor force in the private sector economy (EPoD, 2015).

\section{Bibliography}

Al-Aaili, La'aleh (2014). “Nationalization: A Case from the Middle East 'Kingdom of Bahrain'”, PhD Thesis, University of Manchester.

Aw, B.-Y., and Amy Ruey-meng Hwang. (1995) "Productivity and the Export Market: A FirmLevel Analysis.” Journal of Development Economics 47 (2): 313-332.

Bernard, Andrew B. (2006) “Firms in International Trade”. NBER Reporter Research Summary Fall 2006. https://www.nber.org/reporter/fall06/bernard.html

Bernard, Andrew B. and J.B. Jensen (1999a). "Exceptional Exporter Performance: Cause, Effect, or Both?” Journal of International Economics 47: 1-25

Bernard, Andrew B., J Bradford Jensen, Stephen J. Redding and Peter K. Schott (2018) “Global Firms” Journal of Economic Literature 2018, 56(2), 265-619.

Calonico, Sebastian, Matias D. Cattaneo and Rocio Titiunik (2014). "Robust data-drien inference in the regression-discontinuity design”. The Stata Journal 14(4): 909-946. 
Castellani, Davide. (2002) “Export Behavior and Productivity Growth: Evidence from Italian Manufacturing Firms.” Weltwirtschaftliches Archiv 138 (4): 605-28.

Cattaneo, Matias D, Rocio Titiunik, and Gonzalo Vazquez-Bare. (2019). "Power calculations for regression-discontinuity designs”. The Stata Journal 19(1): 210-245.

Chay, Kenneth Y. (1998) "The Impact of Federal Civil Rights Policy on Black Economic Progress: Evidence from the Equal Employment Opportunity Act of 1972.” ILR Review 51 (4): 608-32.

Chin, Aimee, and Nishith Prakash. (2011). "The redistributive effects of political reservation for minorities: Evidence from India.” Journal of Development Economics 96 (2): 265-77.

Clemens, Michael A., Ethan G Lewis and Hannah M. Postel (2018) "Immigration Restrictions as Active Labor Market Policy: Evidence from the Mexican Bracero Exclusion”. American Economic Review, 108(6): June 2018, pages 1468-87.

Census. A profile of U.S. Importing and Exporting Companies, 2015-2016. Accessed https://www.census.gov/foreign-trade/Press-Release/edb/2016/text.pdf

Crump, Richard K., V. Joseph Hotz, Guido W. Imbens, and Oscar A. Mitnik. (2009) "Dealing with limited overlap in estimation of average treatment effects." Biometrika 96, no. 1: 187-199.

Dustmann, Christian, Uta Schönberg and Jan Stuhler (2016). “The Impact of Immigration: Why do Studies Reach such Different Results?” Journal of Economic Perspectives, 30 (4),31-56, 2016.

Evidence for Policy Design, EPoD (2015). "Back to Work in a New Economy: Background paper on the Saudi Labor Market”. https://epod.cid.harvard.edu/sites/default/files/inlinefiles/hks-mol_background_paper__full___april_2015.pdf 
Hertog, Steffen. (2014) “Arab Gulf States: An Assessment of Nationalisation Policies.” Gulf Labour Markets and Migration (GLMM) Research Paper 1/2014

Holzer, Harry, and David Neumark. (2000). “Assessing Affirmative Action.” Journal of Economic Literature 38 (3): 483-568.

Howard, Larry L., and Nishith Prakash. (2012). "Do employment quotas explain the occupational choices of disadvantaged minorities in India?” International Review of Applied Economics 26 (4):489-513.

Lewis, Ethan. (2011). “Immigration, Skill Mix, and Capital Skill Complementarity.” Quarterly Journal of Economics 126(2): 1029-69.

Melitz, Marc J. (2003). “The Impact of Trade on Intra-industry Reallocations and Aggregate Industry Productivity.” Econometrica 71 (6): 1695-1725.

Miller, Conrad, Jennifer Peck and Mehmet Seflek (forthcoming) "Missing Women, Integration Costs, and Big Puch Policies in the Saudi Labor Market”. American Economic Journal: Applied Economics.

National Association of Manufacturers. (2019) United States Manufacturing Facts. Accessed https://www.nam.org/state-manufacturing-data/2019-united-states-manufacturing-facts/

Ottaviano, Gianmarco, Giovanni Peri and Greg C. Wright. (2018). "Immigration, trade and productivity in services: Evidence from U.K. firms”. Journal of International Economics, vol 112, pages 88-108.

Peck, Jennifer (2017) “Can Hiring Quotas Work? The Effect of the Nitaqat Program on the Saudi Private Sector.” American Economic Journal: Economic Policy, May 2017: 9(2). 316-347 
Park, Albert, Dean Yang, Xinzheng Shi and Yuan Jian. (2010). "Exporting and Firm Performance: Chinese Exporters and the Asian Financial Crisis”. The Review of Economics and Statistics, 92(4): 822-842.

Prakash, Nishith. (2009). "Improving the Labor Market Outcomes of Minorities: The Role of Employment Quota.” Institute for the Study of Labor (IZA) Discussion Paper 4386.

Ramady, M. (2013). "Gulf unemployment and government policies: Prospects for the Saudi labour quota or Nitaqat system." International Journal of Economics and Business Research 5 (4): 476-98.

Sadi, Muhammad Asad. (2013). "The Implementation Process of Nationalization of Workforce in Saudi Arabian Private Sector: A Review of 'Nitaqat Scheme.'” American Journal of Business and Management

2 (1): 37-45. 
Figure 1. Trends in Exports by Nitaqat Status (Balanced Sample)

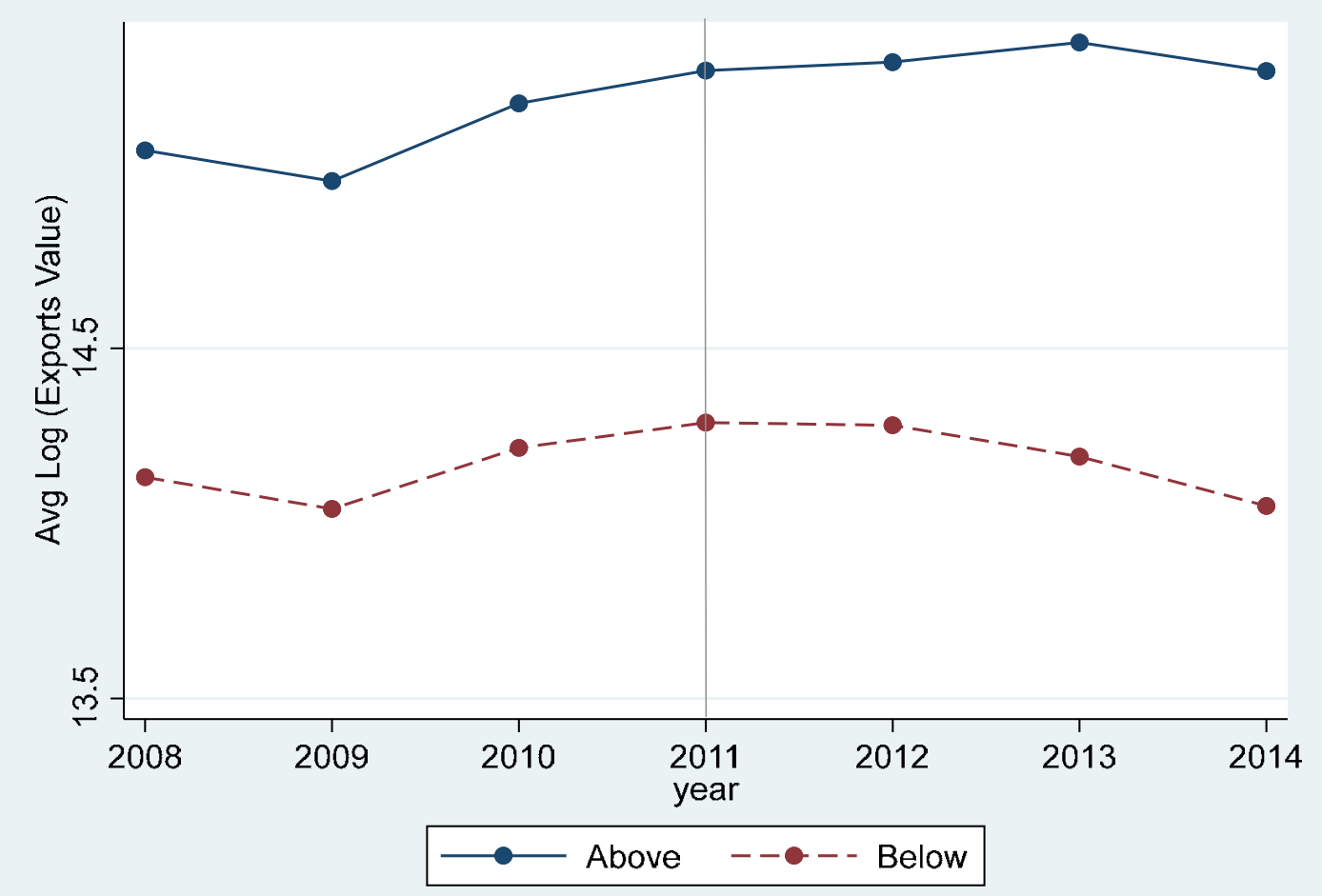

Notes: Balanced sample is restricted to observations with a propensity score between 10 and $90 \%$. 
Figure 2. Trends in Labor Outcomes (Balanced Sample)- GOSI data
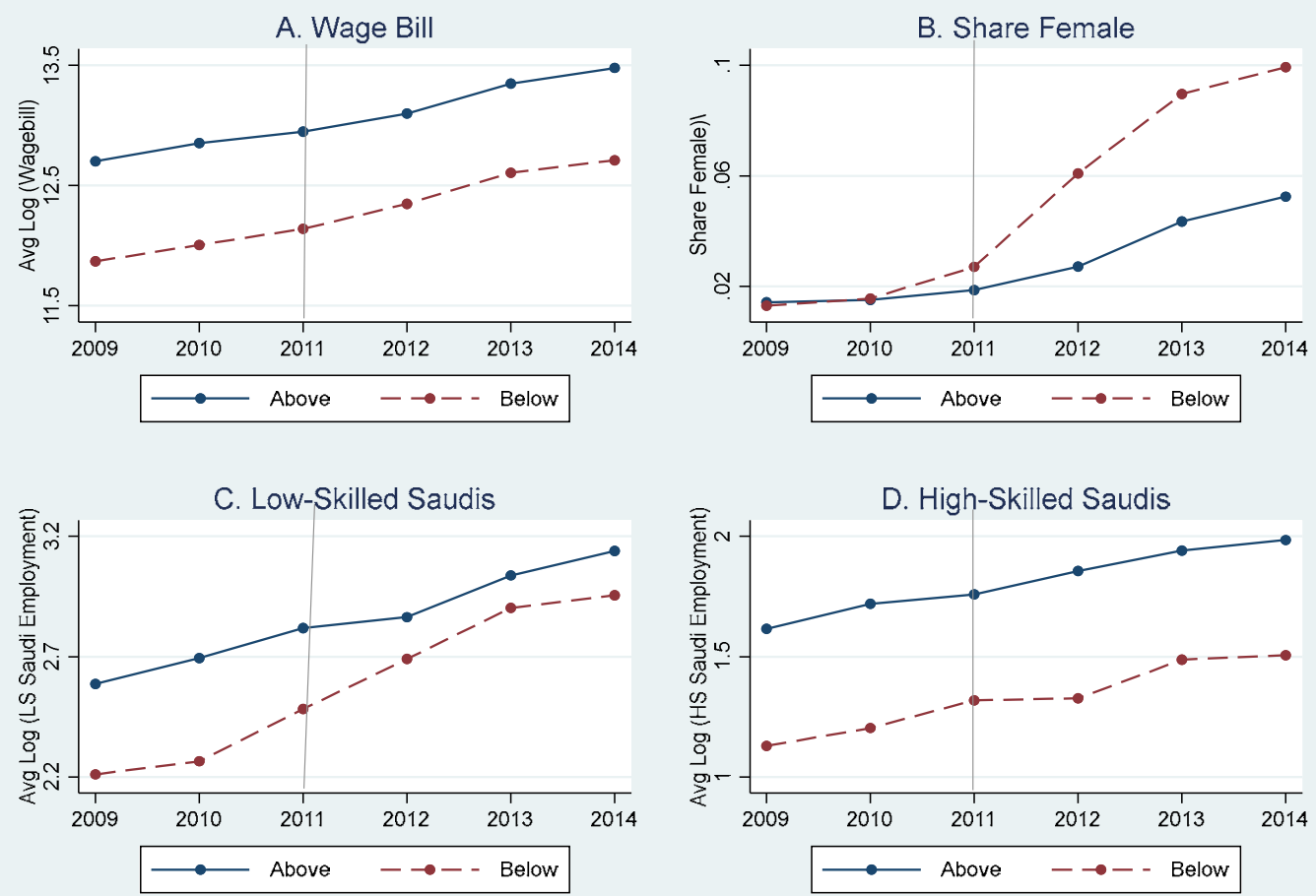

Notes: Balanced sample is restricted to observations with a propensity score between 10 and $90 \%$. 
Figure 3. Event Study Analysis of Exports
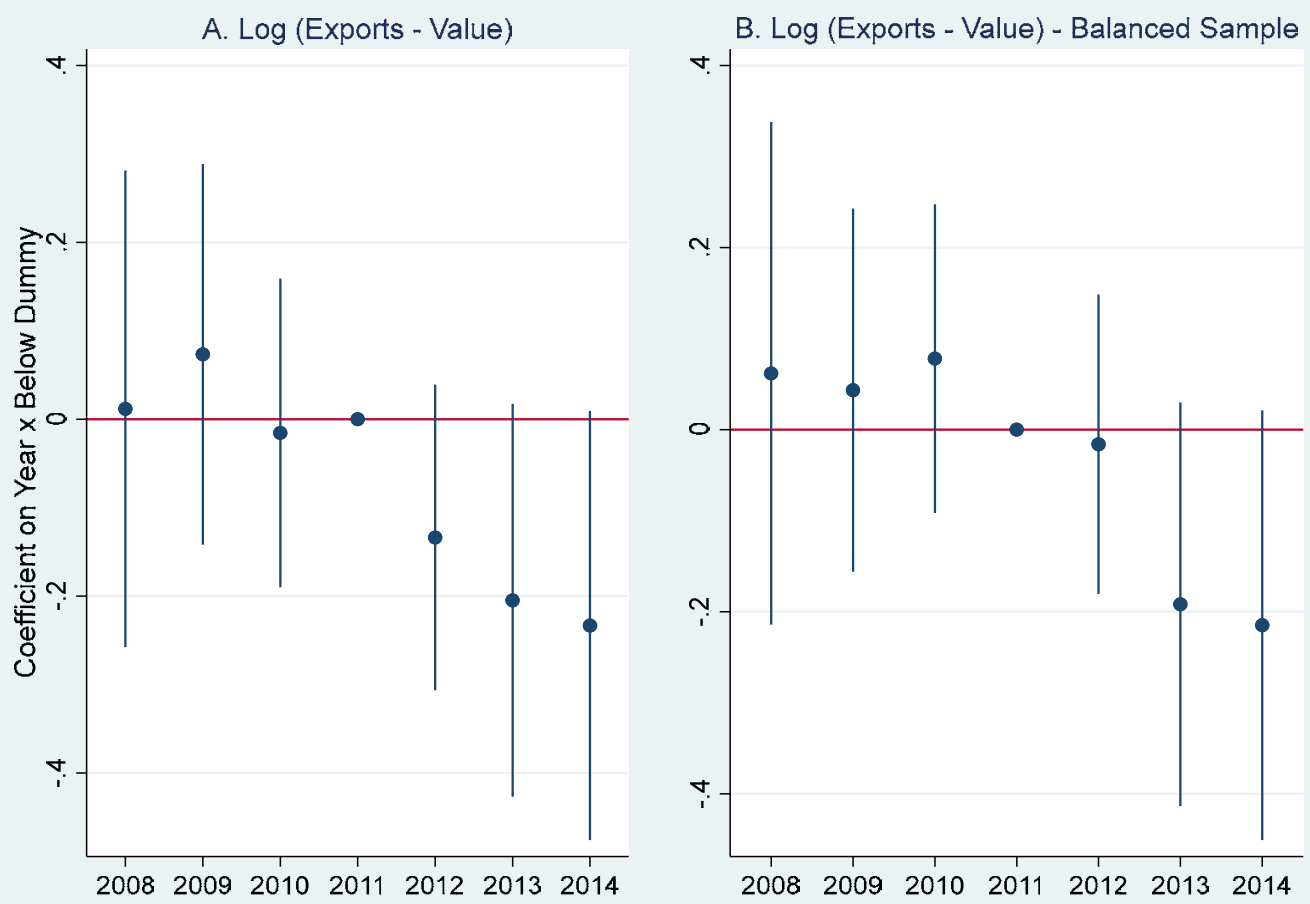

Note: The coefficients are estimated based on specification (2) in the text. Lines show the 95\% confidence interval. Sample is restricted to observations with a propensity score between 10 and $90 \%$. Standard errors clustered at the firm level. 
Figure 4. Event study analysis of GOSI Firm Level Labor Outcomes (Balanced Panel)

A. Wagebill

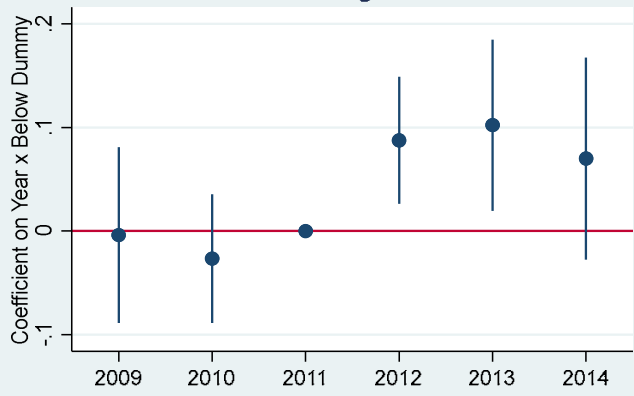

C.Low-Skilled Saudi Employment

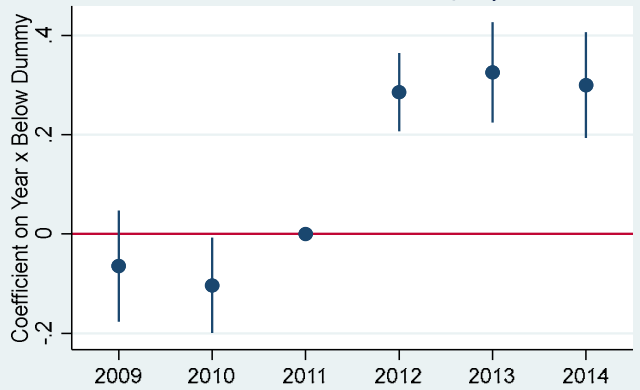

B. Share Female in Saudi Employment

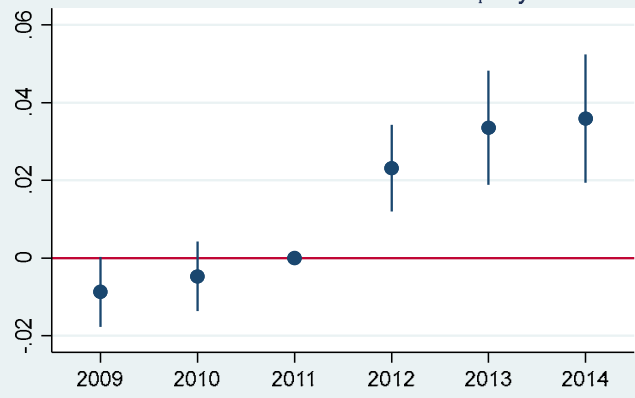

D.High-Skilled Saudi Employment

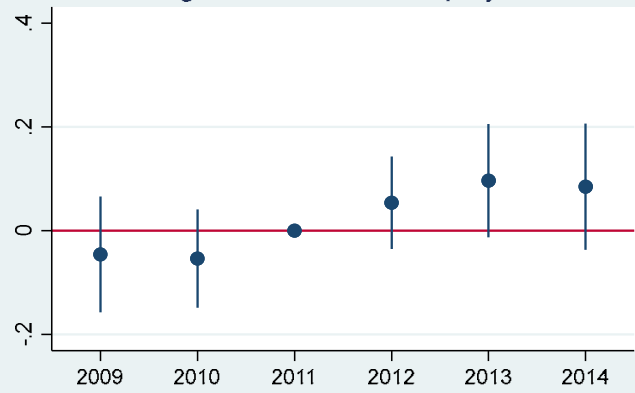

Note: The coefficients are estimated based on specification (2) in the text. Lines show the 95\% confidence interval. Sample is restricted to observations with a propensity score between 10 and $90 \%$. Standard errors clustered at the firm level. 
Figure 5. Binscatters of Distance from Threshold and Outcomes
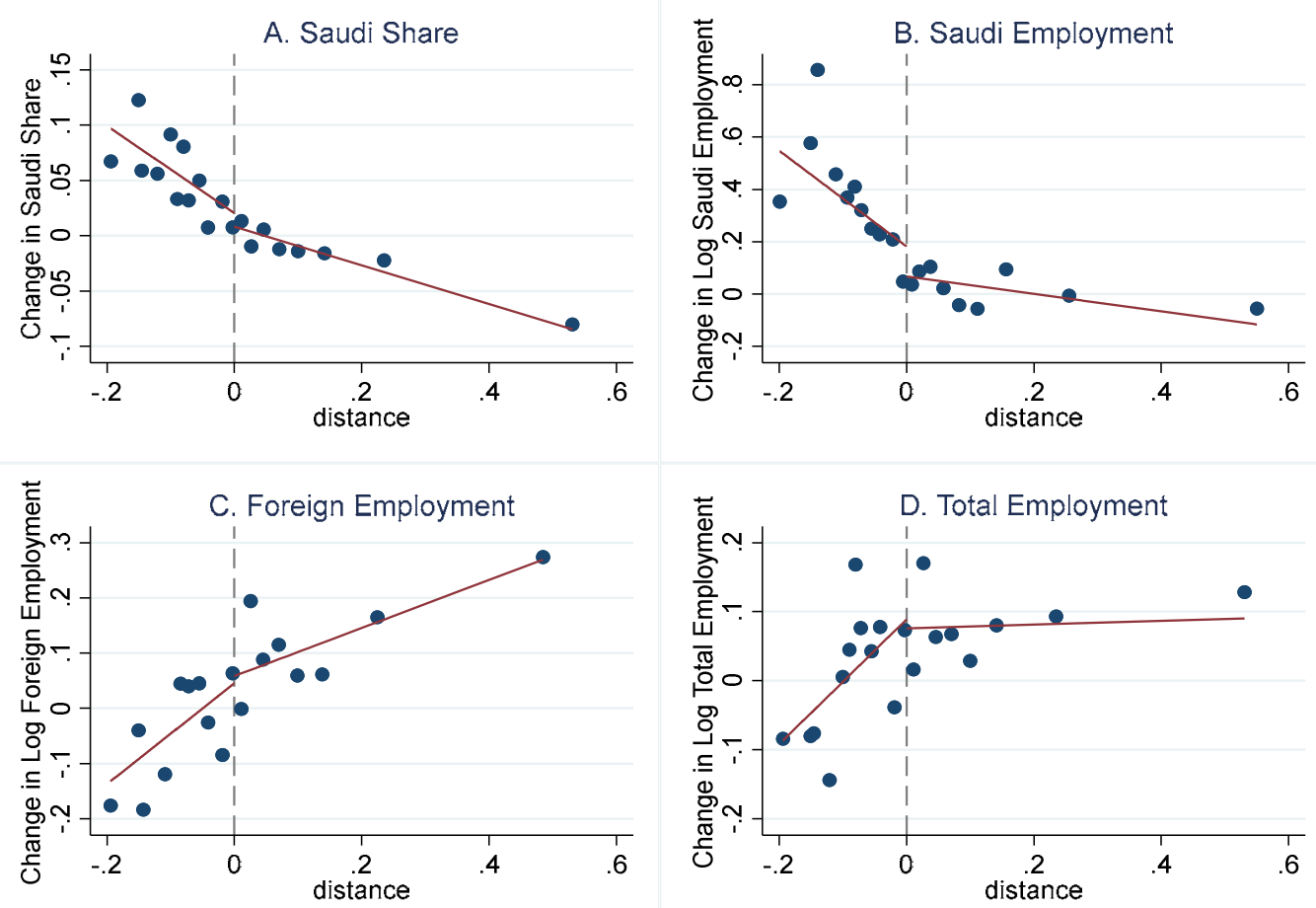

Notes: The figures represent binscatters and linear regressions using the individual data, estimated separately by below status. Distance is measured as firm's Saudi share minus the threshold for the green band. Sample is restricted to firms with propensity scores between 10 and $90 \%$. 
Table 1. Comparison of Exporting vs non-Exporting Firms, July 2011

\begin{tabular}{|c|c|c|}
\hline & Non-Exporters & Exporters \\
\hline \multicolumn{3}{|l|}{ Size (\%) } \\
\hline Micro (1-9) & 0.60 & 0.09 \\
\hline Small (10-49) & 0.33 & 0.28 \\
\hline Medium (50-499) & 0.06 & 0.50 \\
\hline Large (500-2999) & 0.01 & 0.12 \\
\hline Giant $(3000+)$ & 0.00 & 0.01 \\
\hline \multicolumn{3}{|c|}{ Sample restricted to Firms $10+$ employees } \\
\hline Number of Employees & 54.78 & 421.60 \\
\hline Share Saudi & 0.07 & 0.19 \\
\hline No Saudis in labor force & 0.57 & 0.11 \\
\hline \multicolumn{3}{|l|}{ Nitaqat Bands } \\
\hline Red & 68.3 & 34.2 \\
\hline Yellow & 10.8 & 24.6 \\
\hline Green & 18.8 & 31.3 \\
\hline Platinum & 2.1 & 9.9 \\
\hline Share Low-skilled in Saudis & 0.84 & 0.83 \\
\hline Share Female in Saudis & 0.07 & 0.02 \\
\hline \multicolumn{3}{|l|}{ Sector } \\
\hline Agriculture & 0.01 & 0.02 \\
\hline Mining and Oil & 0.01 & 0.03 \\
\hline Manufacturing & 0.08 & 0.57 \\
\hline Electricity, gas and water & 0.00 & 0.01 \\
\hline Construction & 0.51 & 0.05 \\
\hline Retail and Wholesale & 0.26 & 0.19 \\
\hline Post and telecommunications & 0.02 & 0.01 \\
\hline FIRE and Business Services & 0.07 & 0.08 \\
\hline Other Social services & 0.05 & 0.02 \\
\hline Exited by 2012 & 0.020 & 0.011 \\
\hline Number of Observations* & 63,968 & 1,142 \\
\hline
\end{tabular}

* Excludes micro firms.

Note: Data comes from Nitaqat and GOSI datasets. 
Table 2. Descriptive Statistics for Exporting Firms by Nitaqat Status - July 2011

\begin{tabular}{|c|c|c|c|c|c|c|}
\hline & \multicolumn{6}{|c|}{ Sample } \\
\hline & \multicolumn{3}{|c|}{ All Firms } & \multicolumn{3}{|c|}{ Excluding Platinium Firms } \\
\hline & Above & Below & Difference & Above & Below & Difference \\
\hline $\begin{array}{l}\text { Total Exports } \\
\text { (Millions of SARS) }\end{array}$ & $\begin{array}{l}58.87 \\
(287.5)\end{array}$ & $\begin{array}{c}6.973 \\
(33.87)\end{array}$ & $51.90 * * *$ & $\begin{array}{c}16.53 \\
(105.9)\end{array}$ & $\begin{array}{c}6.973 \\
(33.87)\end{array}$ & $9.557 *$ \\
\hline Saudi Employees & $\begin{array}{c}94.35 \\
(273.3)\end{array}$ & $\begin{array}{c}45.18 \\
(316.6)\end{array}$ & $49.17 * *$ & $\begin{array}{c}74.26 \\
(263.4)\end{array}$ & $\begin{array}{c}45.18 \\
(316.6)\end{array}$ & 29.08 \\
\hline Foreign Employees & $\begin{array}{c}278.2 \\
(2442.8)\end{array}$ & $\begin{array}{c}410.8 \\
(4973.2)\end{array}$ & -132.6 & $\begin{array}{c}336.9 \\
(2800.5)\end{array}$ & $\begin{array}{c}410.8 \\
(4973.2)\end{array}$ & -73.92 \\
\hline Total Employees & $\begin{array}{c}372.5 \\
(2630.9)\end{array}$ & $\begin{array}{c}456.0 \\
(5284.4)\end{array}$ & -83.43 & $\begin{array}{c}411.1 \\
(3011.4)\end{array}$ & $\begin{array}{c}456.0 \\
(5284.4)\end{array}$ & -44.84 \\
\hline Share Saudis & $\begin{array}{c}0.286 \\
(0.194)\end{array}$ & $\begin{array}{c}0.121 \\
(0.125)\end{array}$ & $0.166^{* * *}$ & $\begin{array}{c}0.213 \\
(0.116)\end{array}$ & $\begin{array}{c}0.121 \\
(0.125)\end{array}$ & $0.0924 * * *$ \\
\hline Share Manufacturing & $\begin{array}{c}0.739 \\
(0.440)\end{array}$ & $\begin{array}{c}0.670 \\
(0.471)\end{array}$ & $0.0688 *$ & $\begin{array}{c}0.713 \\
(0.453)\end{array}$ & $\begin{array}{c}0.670 \\
(0.471)\end{array}$ & 0.0429 \\
\hline Share Trade & $\begin{array}{c}0.122 \\
(0.328)\end{array}$ & $\begin{array}{c}0.181 \\
(0.385)\end{array}$ & $-0.0587 *$ & $\begin{array}{c}0.130 \\
(0.336)\end{array}$ & $\begin{array}{c}0.181 \\
(0.385)\end{array}$ & $-0.0515^{*}$ \\
\hline No. Obs & 470 & 672 & & 357 & 672 & \\
\hline
\end{tabular}


Table 3. Effects of Nitaqat on Firm Size and Employment Composition (Nitaqat Data)

\begin{tabular}{lcccccc}
\hline \hline \multirow{2}{*}{ Dependent Var: } & \multicolumn{3}{c}{ Coefficient on Below Indicator Var: } & \multicolumn{2}{c}{ Mean Dep. Var. Above } \\
& $(1)$ & $(2)$ & $(3)$ & $(4)$ & & \\
Saudi Share & $0.076^{* * *}$ & $0.075^{* * *}$ & $0.066^{* * *}$ & $0.066^{* * *}$ & -0.016 & -0.006 \\
& $(0.008)$ & $(0.008)$ & $(0.007)$ & $(0.007)$ & & \\
$\Delta$ Log Saudi Employment & $0.347^{* * *}$ & $0.347^{* * *}$ & $0.343^{* * *}$ & $0.361^{* * *}$ & 0.019 & 0.022 \\
& $(0.042)$ & $(0.041)$ & $(0.044)$ & $(0.044)$ & & \\
& $-0.153^{* * *}$ & $-0.143^{* * *}$ & $-0.120^{* * *}$ & $-0.106^{* * *}$ & 0.111 & 0.078 \\
$\Delta$ Log Foreign Employment & $(0.030)$ & $(0.030)$ & $(0.030)$ & $(0.030)$ & & \\
& $-0.071^{* *}$ & $-0.063^{* *}$ & $-0.055^{*}$ & -0.038 & 0.076 & 0.059 \\
$\Delta$ Log Total Employment & $(0.032)$ & $(0.031)$ & $(0.032)$ & $(0.032)$ & & \\
No. Observations & 896 & 896 & 805 & 805 & 389 & 298 \\
Fixed Effects Included & No & Yes & No & Yes & & No \\
Sample & All & All & No & No & All & Platinum \\
\hline
\end{tabular}

Note: Robust standard errors in parenthesis. Each number comes from a different regression. Fixed effects are economic activity fixed effects, region fixed effects, and size fixed effects. All regressions are unweighted. Samples are restricted to observations with a propensity score between 10 and $90 \%$. See text page 13 for details. *** $\mathrm{p}<0.01$, $* * \mathrm{p}<0.05, * \mathrm{p}<0.1$ 


\begin{tabular}{|c|c|c|c|c|c|c|}
\hline \multirow[t]{2}{*}{ Dependent Var: } & \multicolumn{4}{|c|}{ Coefficient on Below Indicator Var: } & \multicolumn{2}{|c|}{ Mean Dep. Var. Above } \\
\hline & (1) & (2) & (3) & (4) & & \\
\hline \multirow[t]{2}{*}{ Dummy Exit by $2012^{a}$} & $0.016^{*}$ & $0.016^{*}$ & 0.014 & $0.015^{*}$ & 0.013 & 0.014 \\
\hline & $(0.008)$ & $(0.008)$ & $(0.009)$ & $(0.009)$ & & \\
\hline No. Obs. & 1,138 & 1,138 & 1,026 & 1,026 & & \\
\hline \multirow[t]{2}{*}{ No Exports in 2012 | Not Exiting } & $0.067 * * *$ & $0.065 * * *$ & $0.072 * * *$ & $0.073 * * *$ & 0.171 & 0.165 \\
\hline & $(0.024)$ & $(0.024)$ & $(0.026)$ & $(0.025)$ & & \\
\hline No. Obs. & 1,113 & 1,113 & 1,002 & 1,002 & & \\
\hline \multirow[t]{2}{*}{$\Delta$ Log Total Exports Value } & $-0.134^{*}$ & -0.109 & -0.078 & -0.068 & -0.026 & -0.082 \\
\hline & $(0.081)$ & $(0.083)$ & $(0.089)$ & $(0.092)$ & & \\
\hline No. Obs. & 896 & 896 & 805 & 805 & & \\
\hline \multirow[t]{2}{*}{$\Delta$ Log Total Exports Volume } & $-0.220 *$ & $-0.230 *$ & -0.150 & -0.166 & -0.001 & -0.071 \\
\hline & $(0.122)$ & $(0.130)$ & $(0.129)$ & $(0.135)$ & & \\
\hline No. Obs. & 896 & 896 & 805 & 805 & & \\
\hline \multirow[t]{2}{*}{$\Delta$ Log Export Value per Worker } & -0.063 & -0.046 & -0.023 & -0.030 & -0.102 & -0.141 \\
\hline & $(0.085)$ & $(0.087)$ & $(0.094)$ & $(0.097)$ & & \\
\hline No. Obs. & 896 & 896 & 805 & 805 & & \\
\hline \multirow{2}{*}{$\Delta$ Log Export Volume per Worker } & -0.149 & -0.167 & -0.096 & -0.128 & -0.076 & -0.130 \\
\hline & $(0.124)$ & $(0.131)$ & $(0.133)$ & $(0.138)$ & & \\
\hline No. Obs. & 896 & 896 & 805 & 805 & 389 & 298 \\
\hline \multirow[t]{3}{*}{ Fixed Effects Included } & No & Yes & No & Yes & 308 & 228 \\
\hline & All & All & $\begin{array}{c}\text { No } \\
\text { Platinum }\end{array}$ & $\begin{array}{c}\text { No } \\
\text { Platinum }\end{array}$ & All & $\begin{array}{c}\text { No } \\
\text { Platinum }\end{array}$ \\
\hline & & & Platinum & Platinum & & Platinum \\
\hline${ }^{\mathrm{a}}$ This outcomes comes from the Nitaqat & dataset, wh & exit is me & asured as $h$ & g appeare & July 2011 & t not in July \\
\hline
\end{tabular}


Table 5. Effects of Nitaqat on the Wage Bill and Employment Composition (GOSI Data)

\begin{tabular}{|c|c|c|c|c|c|c|}
\hline Dependent Var: & \multicolumn{4}{|c|}{ Coefficient on Below Indicator Var: } & \multicolumn{2}{|c|}{ Mean Dep. Var. Above } \\
\hline & (1) & (2) & (3) & (4) & \multirow{4}{*}{0.139} & \multirow{4}{*}{0.144} \\
\hline \multirow[t]{2}{*}{$\Delta$ Log Wage Bill } & $0.091 * * *$ & $0.089 * * *$ & $0.086 * * *$ & $0.093 * * *$ & & \\
\hline & $(0.028)$ & $(0.028)$ & $(0.028)$ & $(0.030)$ & & \\
\hline No. Obs. & 845 & 845 & 757 & 757 & & \\
\hline \multirow[t]{2}{*}{$\Delta$ Log Avg Saudi Wage } & $-0.048 * * *$ & $-0.040 * *$ & $-0.048 * * *$ & $-0.041 * *$ & \multirow[t]{3}{*}{0.074} & \multirow[t]{3}{*}{0.074} \\
\hline & $(0.016)$ & $(0.016)$ & $(0.018)$ & $(0.017)$ & & \\
\hline No. Obs. & 817 & 817 & 729 & 729 & & \\
\hline \multirow[t]{2}{*}{$\Delta$ Log Saudi Empl. Low-skilled } & $0.295 * * *$ & $0.287 * * *$ & $0.282 * * *$ & $0.284^{* * *}$ & \multirow[t]{3}{*}{0.052} & \multirow[t]{3}{*}{0.065} \\
\hline & $(0.038)$ & $(0.038)$ & $(0.040)$ & $(0.041)$ & & \\
\hline No. Obs. & 790 & 790 & 703 & 703 & & \\
\hline \multirow[t]{2}{*}{$\Delta$ Log Saudi Empl. High-skilled } & $0.071^{*}$ & $0.076^{*}$ & $0.077 *$ & $0.084^{*}$ & \multirow[t]{3}{*}{0.079} & \multirow[t]{3}{*}{0.073} \\
\hline & $(0.042)$ & $(0.044)$ & $(0.046)$ & $(0.048)$ & & \\
\hline No. Obs. & 558 & 558 & 483 & 483 & & \\
\hline \multirow[t]{2}{*}{$\Delta$ (Female Saudi/Total Saudi) } & $0.029 * * *$ & $0.027 * * *$ & $0.027 * * *$ & $0.026 * * *$ & \multirow[t]{3}{*}{0.006} & \multirow[t]{3}{*}{0.008} \\
\hline & $(0.006)$ & $(0.006)$ & $(0.006)$ & $(0.006)$ & & \\
\hline No. Obs. & 806 & 806 & 729 & 729 & & \\
\hline Fixed Effects Included & No & Yes & No & Yes & 277 & 289 \\
\hline \multirow[t]{2}{*}{ Sample } & All & All & No & No & \multirow{2}{*}{ All } & No \\
\hline & & & Platinum & Platinum & & Platinum \\
\hline
\end{tabular}

Note: Robust standard errors in parenthesis. Each number comes from a different regression. Fixed effects are economic activity fixed effects, region fixed effects, and size fixed effects. All regressions are unweighted. Samples are restricted to observations with a propensity score between 10 and $90 \%$. See text page 13 for details. ${ }^{* * *} \mathrm{p}<0.01,{ }^{* *} \mathrm{p}<0.05$, * $\mathrm{p}<0.1$ 
Dependent Variable:

\begin{tabular}{|c|c|c|c|c|c|c|}
\hline & \multicolumn{3}{|c|}{ No Exports | Not } & \multirow{2}{*}{$\begin{array}{c}\text { Log Saudi } \\
\text { Employment }\end{array}$} & \multirow{2}{*}{$\begin{array}{l}\text { Log Foreign } \\
\text { Employment }\end{array}$} & $\begin{array}{l}\text { Log Total } \\
\text { Employment }\end{array}$ \\
\hline & DUIIIIy EXIL & & Saudi silate & & & \\
\hline & $(1)$ & $(2)$ & (3) & $(4)$ & $(5)$ & (6) \\
\hline \multirow[t]{2}{*}{ y2012 X below } & -0.009 & $-0.062 * *$ & $0.075^{* * *}$ & $0.312 * * *$ & $-0.185 * * *$ & -0.058 \\
\hline & $(0.006)$ & $(0.027)$ & $(0.008)$ & $(0.043)$ & $(0.033)$ & $(0.103)$ \\
\hline \multirow[t]{2}{*}{ y2013 X below } & -0.006 & $-0.071^{* *}$ & $0.094 * * *$ & $0.366^{* * *}$ & $-0.250 * * *$ & -0.158 \\
\hline & $(0.006)$ & $(0.030)$ & $(0.009)$ & $(0.050)$ & $(0.043)$ & $(0.133)$ \\
\hline \multirow[t]{2}{*}{ y2014 X below } & -0.011 & $-0.085 * * *$ & $0.102^{* * *}$ & $0.353 * * *$ & $-0.327 * * *$ & -0.118 \\
\hline & $(0.008)$ & $(0.031)$ & $(0.009)$ & $(0.054)$ & $(0.054)$ & $(0.142)$ \\
\hline \multirow[t]{2}{*}{ y2015 X below } & $-0.018 * *$ & $-0.144 * * *$ & $0.098 * * *$ & $0.334 * * *$ & $-0.336 * * *$ & 0.025 \\
\hline & $(0.009)$ & $(0.032)$ & $(0.010)$ & $(0.061)$ & $(0.061)$ & $(0.172)$ \\
\hline Firm FE & Yes & Yes & Yes & Yes & Yes & Yes \\
\hline Year FE & Yes & Yes & Yes & Yes & Yes & Yes \\
\hline Observations & 5,690 & 5,530 & 5,530 & 5,317 & 5,494 & 5,530 \\
\hline
\end{tabular}

Note: Standard errors (in parenthesis) are clustered at the firm level. The sample in columns (2) to (6) is restricted to firms that have Nitaqat data for all years between 2011 and 2015. Each column represents a different regression. All regressions are unweighted.

Samples are restricted to observations with a propensity score between 10 and $90 \%{ }^{* * *} \mathrm{p}<0.01,{ }^{* *} \mathrm{p}<0.05,{ }^{*} \mathrm{p}<0.1$ 
Table 7. Effects of Nitaqat on Exporter Firms - Alternative Specification

\begin{tabular}{|c|c|c|}
\hline \multirow{3}{*}{$\begin{array}{l}\text { Dependent Var: } \\
\text { Saudi Share }\end{array}$} & \multicolumn{2}{|c|}{ Coefficients on: } \\
\hline & Distance & Dist.*Below \\
\hline & $\begin{array}{c}-0.173 * * \\
(0.075)\end{array}$ & $\begin{array}{c}-0.325^{* *} \\
(0.138)\end{array}$ \\
\hline$\Delta$ Log Saudi Employment & $\begin{array}{l}-0.272 \\
(0.228)\end{array}$ & $\begin{array}{c}-2.545^{* * *} \\
(0.600)\end{array}$ \\
\hline$\Delta$ Log Foreign Employment & $\begin{array}{c}0.551^{* *} \\
(0.223)\end{array}$ & $\begin{array}{c}0.199 \\
(0.463)\end{array}$ \\
\hline$\Delta$ Log Total Employment & $\begin{array}{c}0.105 \\
(0.286)\end{array}$ & $\begin{array}{c}0.514 \\
(0.579)\end{array}$ \\
\hline Exited in 2012 & $\begin{array}{c}0.033 \\
(0.052)\end{array}$ & $\begin{array}{l}-0.144 \\
(0.109)\end{array}$ \\
\hline No Exports in 2012 Dummy & $\begin{array}{l}-0.117 \\
(0.095)\end{array}$ & $\begin{array}{l}-0.095 \\
(0.253)\end{array}$ \\
\hline$\Delta$ Log Total Exports Value & $\begin{array}{c}0.462 \\
(0.346)\end{array}$ & $\begin{array}{c}-0.192 \\
(0.935)\end{array}$ \\
\hline$\Delta$ Log Wage Bill & $\begin{array}{l}-0.157 \\
(0.255)\end{array}$ & $\begin{array}{l}-0.595 \\
(0.505)\end{array}$ \\
\hline$\Delta$ Log Avg Saudi Wage & $\begin{array}{c}-0.066 \\
(0.043)\end{array}$ & $\begin{array}{c}0.681^{* * *} \\
(0.185)\end{array}$ \\
\hline$\Delta$ Log Saudi Employment Low-skilled & $\begin{array}{c}-0.302 \\
(0.224)\end{array}$ & $\begin{array}{c}-1.904^{* * *} \\
(0.559)\end{array}$ \\
\hline$\Delta$ Log Saudi Employment High-skilled & $\begin{array}{l}0.202 * \\
(0.113)\end{array}$ & $\begin{array}{c}-1.778 * * * \\
(0.452)\end{array}$ \\
\hline$\Delta$ (Female Saudi/Total Saudi) & $\begin{array}{l}-0.022 * \\
(0.012)\end{array}$ & $\begin{array}{c}-0.151 * * \\
(0.070)\end{array}$ \\
\hline $\begin{array}{l}\text { Fixed Effects Included } \\
\text { Sample }\end{array}$ & & \\
\hline
\end{tabular}

Note: These regressions are cross-sectional. The change in outcomes is between July 2011 and July 2012. Distance is defined as Saudi share - threshold for the green band. Robust standard errors in parenthesis. Each coefficient comes from a separate regression. Fixed effects are economic activity fixed effects, region fixed effects and size fixed effects. All regressions are unweighted. Number of observations is the same as in Tables 3 to 5 . Samples are restricted to observations with a propensity score between 10 and $90 \%$. ${ }^{* * *} \mathrm{p}<0.01$, ** $\mathrm{p}<0.05,{ }^{*} \mathrm{p}<0.1$ 
Table 8. Comparison of Effects' Sizes with Non-exporter firms

\begin{tabular}{|c|c|c|c|c|}
\hline \multirow[b]{3}{*}{ Dependent Var: } & \multicolumn{2}{|r|}{ (1) } & \multicolumn{2}{|c|}{ (2) } \\
\hline & \multicolumn{4}{|c|}{ Coefficient on } \\
\hline & Below & Below * Exporter & Below & Below * Exporter \\
\hline \multicolumn{5}{|l|}{ Nitaqat Data } \\
\hline Saudi Share & $\begin{array}{c}0.052 * * * \\
(0.001)\end{array}$ & $\begin{array}{c}0.014^{* *} \\
(0.006)\end{array}$ & $\begin{array}{c}0.043^{* * *} \\
(0.001)\end{array}$ & $\begin{array}{c}0.016^{* * *} \\
(0.006)\end{array}$ \\
\hline$\Delta$ Log Saudi Employment & $\begin{array}{c}0.241 * * * \\
(0.008)\end{array}$ & $\begin{array}{l}0.074 * \\
(0.039)\end{array}$ & $\begin{array}{c}0.219 * * * \\
(0.008)\end{array}$ & $\begin{array}{c}0.112 * * * \\
(0.041)\end{array}$ \\
\hline$\Delta$ Log Foreign Employment & $\begin{array}{c}-0.182 * * * \\
(0.005)\end{array}$ & $\begin{array}{c}0.017 \\
(0.031)\end{array}$ & $\begin{array}{c}-0.159 * * * \\
(0.005)\end{array}$ & $\begin{array}{c}0.044 \\
(0.030)\end{array}$ \\
\hline$\Delta$ Log Total Employment & $\begin{array}{c}-0.120 * * * \\
(0.005)\end{array}$ & $\begin{array}{c}0.029 \\
(0.030)\end{array}$ & $\begin{array}{c}-0.115^{* * *} \\
(0.005)\end{array}$ & $\begin{array}{l}0.057^{*} \\
(0.030)\end{array}$ \\
\hline Dummy Exit by 2012 & $\begin{array}{c}0.009 * * * \\
(0.001)\end{array}$ & $\begin{array}{c}0.001 \\
(0.005)\end{array}$ & $\begin{array}{c}0.009 * * * \\
(0.001)\end{array}$ & $\begin{array}{c}0.001 \\
(0.006)\end{array}$ \\
\hline \multicolumn{5}{|l|}{ GOSI data } \\
\hline$\Delta$ Log Wage Bill & $\begin{array}{c}0.139 * * * \\
(0.006)\end{array}$ & $\begin{array}{c}-0.068 * * \\
(0.030)\end{array}$ & $\begin{array}{c}0.136 * * * \\
(0.006)\end{array}$ & $\begin{array}{c}-0.061 * \\
(0.031)\end{array}$ \\
\hline$\Delta$ Log Avg Saudi Wage & $\begin{array}{c}-0.018^{* * *} \\
(0.003)\end{array}$ & $\begin{array}{l}-0.016 \\
(0.016)\end{array}$ & $\begin{array}{c}-0.019 * * * \\
(0.004)\end{array}$ & $\begin{array}{l}-0.017 \\
(0.018)\end{array}$ \\
\hline$\Delta$ Log Saudi Empl. Low-skilled & $\begin{array}{c}0.175^{* * *} \\
(0.008)\end{array}$ & $\begin{array}{c}0.094 * * \\
(0.039)\end{array}$ & $\begin{array}{c}0.161^{* * *} \\
(0.008)\end{array}$ & $\begin{array}{c}0.118 * * * \\
(0.042)\end{array}$ \\
\hline$\Delta$ Log Saudi Empl. High-skilled & $\begin{array}{c}0.073^{* * *} \\
(0.011)\end{array}$ & $\begin{array}{l}-0.030 \\
(0.044)\end{array}$ & $\begin{array}{c}0.067 * * * \\
(0.011)\end{array}$ & $\begin{array}{l}-0.004 \\
(0.047)\end{array}$ \\
\hline$\Delta$ (Female Saudi/Total Saudi) & $\begin{array}{c}0.013 * * * \\
(0.002)\end{array}$ & $\begin{array}{c}0.011 * * \\
(0.005)\end{array}$ & $\begin{array}{c}0.012 * * * \\
(0.002)\end{array}$ & $\begin{array}{l}0.010 * \\
(0.006)\end{array}$ \\
\hline Fixed Effects Included & Yes & Yes & Yes & Yes \\
\hline Sample & \multicolumn{2}{|c|}{ All firms } & \multicolumn{2}{|c|}{ Drop Platinum } \\
\hline
\end{tabular}

Note: These regressions are cross-sectional. The change in outcomes is between July 2011 and July 2012. Robust standard errors in parenthesis. Each coefficient comes from a separate regression. Fixed effects are economic activity fixed effects, region fixed effects and size fixed effects. All regressions are unweighted. Exporter samples are restricted to observations with a propensity score between 10 and $90 \%$. The number of observations vary between 9588 and 53255. *** $\mathrm{p}<0.01,{ }^{* *} \mathrm{p}<0.05,{ }^{*} \mathrm{p}<0.1$ 
Appendix Figure 1. Trend in the Share of Exporting Firms Below the Threshold by Initial Treatment Status

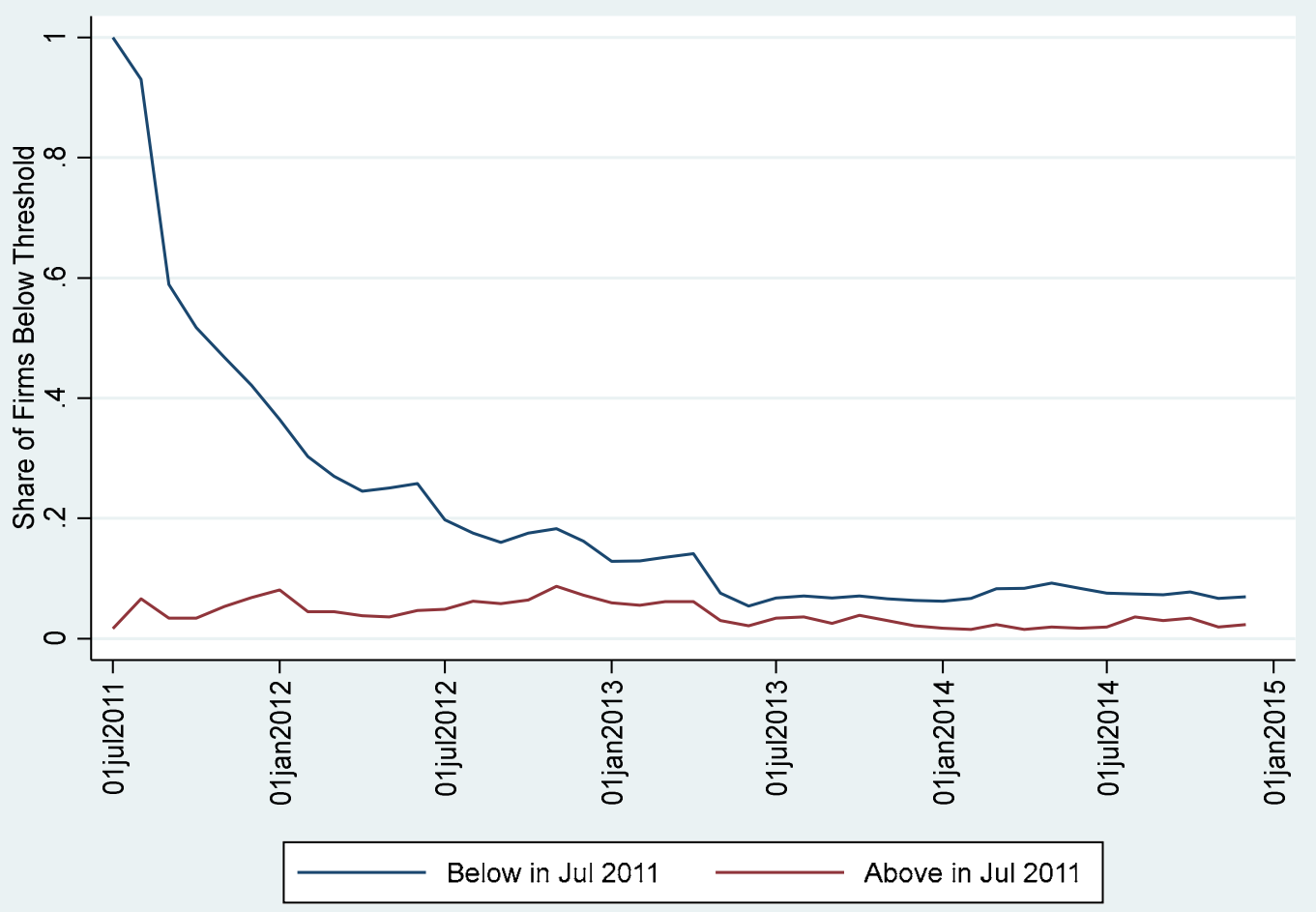


Appendix Figure 2. Distribution of Firms' Distance to the Policy Threshold in July 2011

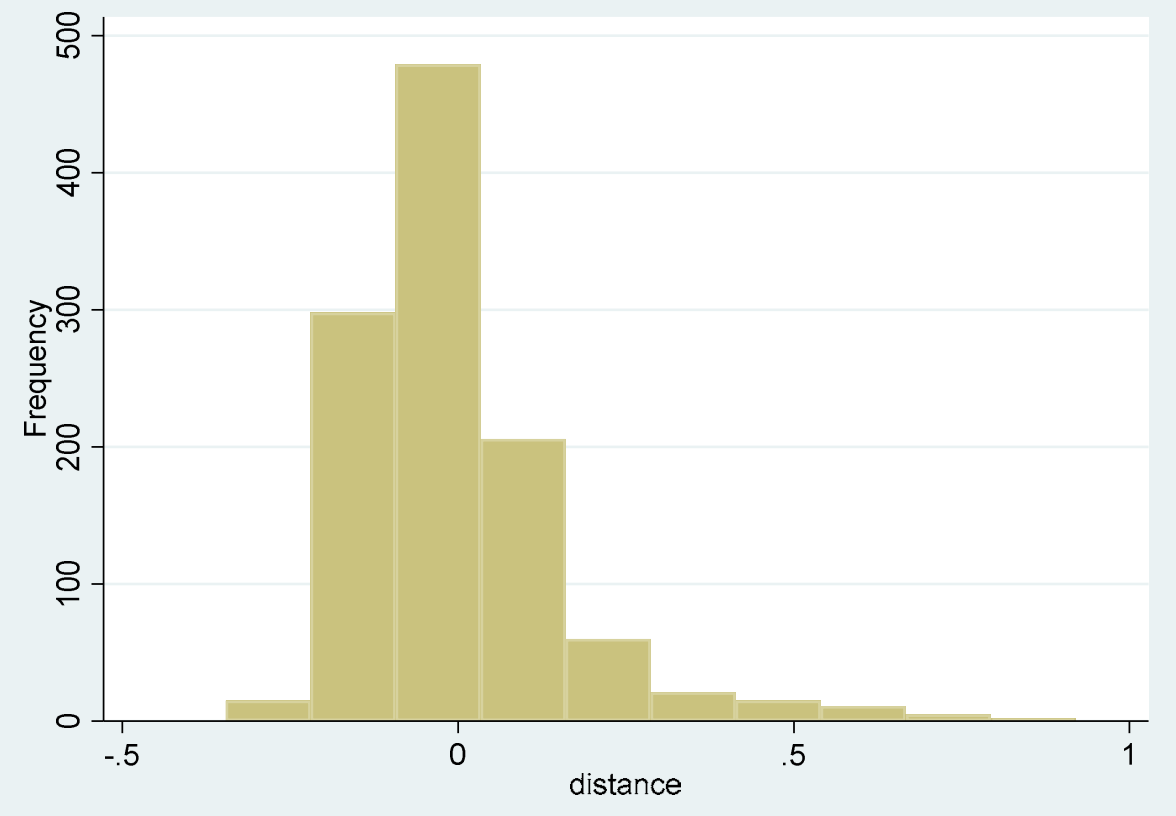

Note: Sample is restricted to firms with propensity score between 10 and $90 \%$. Distance is defined as share saudi - threshold for green band. 


\begin{tabular}{|c|c|c|c|}
\hline & \multicolumn{3}{|c|}{ Samples } \\
\hline & Customs & $\begin{array}{c}\text { Customs \& } \\
\text { Nitaqat }\end{array}$ & $\begin{array}{c}\text { Customs \& } \\
\text { Nitaqat } \\
\text { \&GOSI }\end{array}$ \\
\hline & \multicolumn{3}{|c|}{ Sample: Has data for 2011} \\
\hline Match Rate & & $79 \%$ & $68 \%$ \\
\hline \multicolumn{4}{|l|}{ Characteristics in 2011} \\
\hline Log(Exports - Value) - 2011 & 13.38 & $13.54 * *$ & $13.61 * * *$ \\
\hline Manufacturing & 0.693 & 0.697 & 0.695 \\
\hline Trade & 0.165 & 0.161 & 0.161 \\
\hline Did not Export in 2012 & 0.275 & $0.239 * *$ & $0.228 * * *$ \\
\hline \multirow[t]{2}{*}{ No. Obs. } & 1836 & 1450 & 1251 \\
\hline & \multicolumn{3}{|c|}{ Sample: Has data for 2011 \& 2012} \\
\hline Match Rate & & $83 \%$ & $73 \%$ \\
\hline \multicolumn{4}{|l|}{ Characteristics in 2011} \\
\hline Log(Exports - Value) - 2011 & 13.92 & 14.05 & $14.13^{* *}$ \\
\hline Manufacturing & 0.736 & 0.741 & 0.742 \\
\hline Trade & 0.145 & 0.140 & 0.140 \\
\hline No. Obs & 1331 & 1104 & 966 \\
\hline
\end{tabular}

$* * * \mathrm{p}<0.01, * * \mathrm{p}<0.05, * \mathrm{p}<0.1$. Stars are for the $\mathrm{p}$-value of a test of difference in means with the Customs sample. Number of observations is larger than in Table 1 because here we include micro firms. 